\title{
Pengaruh Wortel (Daucus carota), Jahe (Zingiber officinale Roscoe) dan Temulawak (Curcuma xanthorrhiza Roxb) Terhadap Status Kesehatan Anak Kucing
}

\section{The Effect of Carrot (Daucus carota), Ginger (Zingiber officinale Roscoe) And Temulawak (Curcuma xanthorrhiza Roxb) Against Kitten Health Status}

\author{
Julius Mar'ie Sugata1, Miyayu Soneta Sofyan² \\ 1D3 Student Veterinary Paramedics, Faculty of Vocation, Airlangga University, \\ Surabaya 60115, Indonesia \\ ${ }^{2}$ Lecturers from Department of Health, Vocational Faculty, Airlangga University, \\ Surabaya 60115, Indonesia \\ *email: miyayu@vokasi.unair.ac.id
}

\begin{abstract}
ABSTRAK
Anak kucing diklasifikasikan dalam tahapan pertumbuhan kehidupan dan memiliki kebutuhan energi dan protein yang tinggi. Saat memberi makan anak kucing disarankan menggunakan bahan yang sangat mudah dicerna dan berbagai nutrisi untuk membantu perkembangannya sehingga menghasilkan kucing dewasa yang sehat. Sistem pencernaan kucing bertanggung jawab untuk mencerna makanan dan menyerap nutrisi yang dibutuhkan tubuh. Gastrointestinal adalah rumah bagi mikroflora, juga dikenal sebagai bakteri 'menguntungkan', yang berkontribusi pada kesehatan pencernaan dengan meningkatkan kesehatan secara keseluruhan jika seimbang dan mendukung pemrosesan makanan dan nutrisi. Sistem pencernaan mencakup populasi sel sistem kekebalan yang padat, yang berarti saluran pencernaan
\end{abstract}


kucing adalah salah satu tempat pertama sistem kekebalan menghadapi patogen potensial atau hal lain yang mungkin memerlukan tanggapan kekebalan.

Kata Kunci: Pembibitan / Anak Kucing, Status Kesehatan, Jahe, Wortel, Temulawak, Berat Badan.

\begin{abstract}
Kittens are classified in the stages of life growth and have high energy and protein requirements. When feeding kitten is recommended to use ingredients that are very easy to digest and various nutrient to assist the development to produce healthy adult cats. The cat's digestive system is responsible for digesting food and absorbing the nutrients the body needs. The gastrointestinal is home of microflora, also known as 'beneficial' bacteria, which contributes to digestive health by improving overall health when balanced and supports food and nutrition processing. System digestion includes a dense population of immune system cells, which means the cat's gastrointestinal tract is one of the first places the immune system faces potential pathogens or other things that might require an immune response.
\end{abstract}

Keywords: Disgetion / Kitten, Health Status, Ginger, Carrot, Temulawak, Body Weight.

\section{INTRODUCTION}

Cats are carnivores. The digestive system of cats adapts in such a way that they are only able to digest animal elements both mechanical and enzymatic. The sense of taste becomes very important which is the mechanism by which animals choose their food to meet their daily needs. Cats do not have sweet tasting derived from vegetable elements, but cats are more adaptable to bitter tasting.

These bitter receptors are very important for detecting and preventing cats from ingesting bitter nutrients, which are commonly found in poisonous plants, animals or toxic materials. Cats like the 
solid and moist form of feed and like the fishy taste and dislike powder, sticky or oily feed. Cats that are carnivores are very dependent to meet the nutritional needs of animal-sourced feed (Triakoso, 2016).

Research by Hewson-Hughes et al (2011) provides a very clear picture of the nutritional needs of cats, especially macronutrients namely protein, fat and carbohydrates. In a day a cat needs about 26 grams of protein, 9 grams of fat and 8 grams of carbohydrates, which are the nutritional elements equivalent to the calorie needs of $52 \%$ of protein, $36 \%$ of fat and $12 \%$ of carbohydrate. In addition this study also revealed that cats have a calorie adequacy limit carbohydrate that is equal to $300 \mathrm{~kJ} /$ day. When the cat has reached this limit, it will suppress other food intake both protein and fat (Hewson-Hughes AK, 2011).

Cats need essential nutrients such as arginine, thiamine, taurine, vitamin $\mathrm{A}$, vitamin D, Niacin, linoleic acid, arachidonic acid. Arginine is needed in the urea cycle. As a protein eater, the rest of metabolism in the form of ammonia will be very abundant. In cats that feed arginine-deficient feed, cats will experience hyperammonemia in one hour. Arginine is needed by the body to convert ammonia into water-soluble urea and can be excreted in urine. (Triakoso, 2016)

\section{MATERIALS AND METHODS}

The research has done in $\mathrm{Mr}$. Firlian's pet care in Pekukuhan Hamlet, Pekukuhan Village, Mojosari District, Mojokerto Regency, East Java for one month, from 17 February 2020 to 9 March 2020. On 27 January 2020 proximate Analysis Examination of cat feed samples was conducted by Mr. Firlian in the Veterinary Testing and Feed Analysis Unit of the Faculty of Veterinary Medicine, Airlangga University. Using seven female kitten and eight male kitten.

\section{Research variables and measurement}

The variables in this study can be identified as exogenous and endogenous 
variables. Where the feeding of cats with carrots, ginger, and temulawak as an independent or exogenous variable and body weight and kitten health as a dependent or endogenous variable.

\section{RESULTS AND DISCUSSION}

The results from examining cat feed on pet care owned by Mr. Firlian produces the following:
Table 1. Nutritional content of feed.

\begin{tabular}{|l|c|c|c|c|c|}
\hline Ingredients & $\mathbf{B K} \%$ & $\mathbf{P K} \%$ & $\mathbf{L K} \%$ & $\mathbf{S K} \%$ & $\mathbf{A B U} \%$ \\
\hline Cat Feed & 20,12 & 12,14 & 5,4 & 0,65 & 1,63 \\
\hline
\end{tabular}

Source: Results of analysis of estimated cat feed in pet care Firlian from the Veterinary testing unit, feed analysis from the Faculty of Veterinary Medicine, Airlangga University.

Table 2. Kitten Weight and Digisbility Based on Feces

\begin{tabular}{|c|c|c|c|c|c|}
\hline Kitten & Parameter & \multicolumn{4}{|c|}{ Weeks } \\
\cline { 3 - 6 } & & I & II & III & IV \\
\hline \multirow{4}{*}{1} & Body Weight (gr) & 407,85 & 409 & 412,5 & 415,5 \\
\cline { 2 - 6 } & Daily Feed (gr) & 150 & 150 & 150 & 150 \\
\cline { 2 - 6 } & Feces & Soft & Normal & Normal & Normal \\
\hline \multirow{3}{*}{2} & Body Weight (gr) & 415 & 417,5 & 419 & 420,5 \\
\cline { 2 - 6 } & Daily Feed (gr) & 150 & 150 & 150 & 150 \\
\cline { 2 - 6 } & Feces & Normal & Normal & Soft & Soft \\
\hline \multirow{4}{*}{3} & Body Weight (gr) & 475,5 & 477 & 479 & 480 \\
\cline { 2 - 6 } & Daily Feed (gr) & 150 & 150 & 150 & 150 \\
\cline { 2 - 6 } & Feces & Normal & Soft & Normal & Normal \\
\hline \multirow{4}{*}{4} & Body Weight (gr) & 504,5 & 506 & 507,5 & 509 \\
\cline { 2 - 6 } & Daily Feed (gr) & 150 & 150 & 150 & 150 \\
\cline { 2 - 6 } & Feces & Normal & Normal & Normal & Normal \\
\hline \multirow{4}{*}{5} & Body Weight (gr) & 503,5 & 505 & 507 & 509 \\
\cline { 2 - 6 } & Daily Feed (gr) & 150 & 150 & 150 & 150 \\
\cline { 2 - 6 } & Feces & Normal & Normal & Normal & Normal \\
\hline \multirow{3}{*}{6} & Body Weight (gr) & 456 & 457 & 458,5 & 459 \\
\cline { 2 - 6 } & Daily Feed (gr) & 150 & 150 & 150 & 150 \\
\cline { 2 - 6 } & Feces & Soft & Soft & Normal & Normal \\
\hline \multirow{3}{*}{7} & Body Weight (gr) & 443,5 & 445 & 446,5 & 448 \\
\cline { 2 - 6 } & Daily Feed (gr) & 150 & 150 & 150 & 150 \\
\cline { 2 - 6 } & Feces & Normal & Normal & Soft & Normal \\
\hline \multirow{3}{*}{8} & Body Weight (gr) & 502 & 504 & 506,5 & 509,5 \\
\cline { 2 - 6 } & Daily Feed (gr) & 150 & 150 & 150 & 150 \\
\hline
\end{tabular}

(C)2020. Sugata et al. Open access under CC BY - SA license, doi: 10.20473/mkh.v31i2.2020.85-96 Received: 06-07-2020, Accepted: 25-08-2020, 


\begin{tabular}{|c|c|c|c|c|c|}
\hline & Feces & Normal & Normal & Normal & Normal \\
\hline \multirow{4}{*}{9} & Body Weight (gr) & 483 & 485,5 & 487,5 & 489 \\
\cline { 2 - 6 } & Daily Feed (gr) & 150 & 150 & 150 & 150 \\
\cline { 2 - 6 } & Feces & Normal & Normal & Normal & Soft \\
\hline \multirow{4}{*}{10} & Body Weight (gr) & 407 & 409,5 & 408 & Dead \\
\cline { 2 - 6 } & Daily Feed (gr) & 150 & 150 & 150 & Dead \\
\cline { 2 - 6 } & Feces & Soft & Soft & Soft & Dead \\
\hline \multirow{4}{*}{11} & Body Weight (gr) & 415,5 & 417 & Dead & Dead \\
\cline { 2 - 6 } & Daily Feed (gr) & 150 & 150 & Dead & Dead \\
\cline { 2 - 6 } & Feces & Normal & Soft & Dead & Dead \\
\hline \multirow{4}{*}{13} & Body Weight (gr) & 464,5 & 465 & 467,5 & 470 \\
\cline { 2 - 6 } & Daily Feed (gr) & 150 & 150 & 150 & 150 \\
\cline { 2 - 6 } & Feces & Normal & Soft & Soft & Normal \\
\hline & Body Weight (gr) & 407,5 & 409 & Dead & Dead \\
\cline { 2 - 6 } & Daily Feed (gr) & 150 & 150 & Dead & Dead \\
\cline { 2 - 6 } & Feces & Soft & Soft & Dead & Dead \\
\hline \multirow{3}{*}{14} & Body Weight (gr) & 452 & 454,5 & 456 & 459 \\
\cline { 2 - 6 } & Daily Feed (gr) & 150 & 150 & 150 & 150 \\
\cline { 2 - 6 } & Feces & Soft & Normal & Normal & Soft \\
\hline \multirow{4}{*}{15} & Body Weight (gr) & 410,5 & 413 & Dead & Dead \\
\cline { 2 - 6 } & Daily Feed (gr) & 150 & 150 & Dead & Dead \\
\cline { 2 - 6 } & Feces & Normal & Soft & Dead & Dead \\
\hline
\end{tabular}

The author uses Body Condition Scoring to determine the body goal of a kitten. The following is Body Condition Scoring

The parameters of each score are:

1. When viewed from above, the animal's waist still looks shaped

2. When viewed from the side of the ribs palpable 1 layer of muscle
3. When viewed from the side, the lower abdominal area looks slim, not too thin but not palpated with excess fat.

For animals with long hair, it needs to be touched, because it tends to look "fat" or normal even though the animal could actually be underweight. Body condition score (BCS) used is a score of $1-9$, where the thinnest score is 1 and the fattest 9 . The ideal number is at 4-5. (Dede, 2012). It is known from the data above that the 
kitten weight shows that every week there is an increase of 2-5 gr. Calculation of kitten body weight is done every day using baby scales and then divided on average, so that the average weight can be known. The following is a graph of weight results per week.

Figure 1. The Weight Chart of the Week Kitten Body

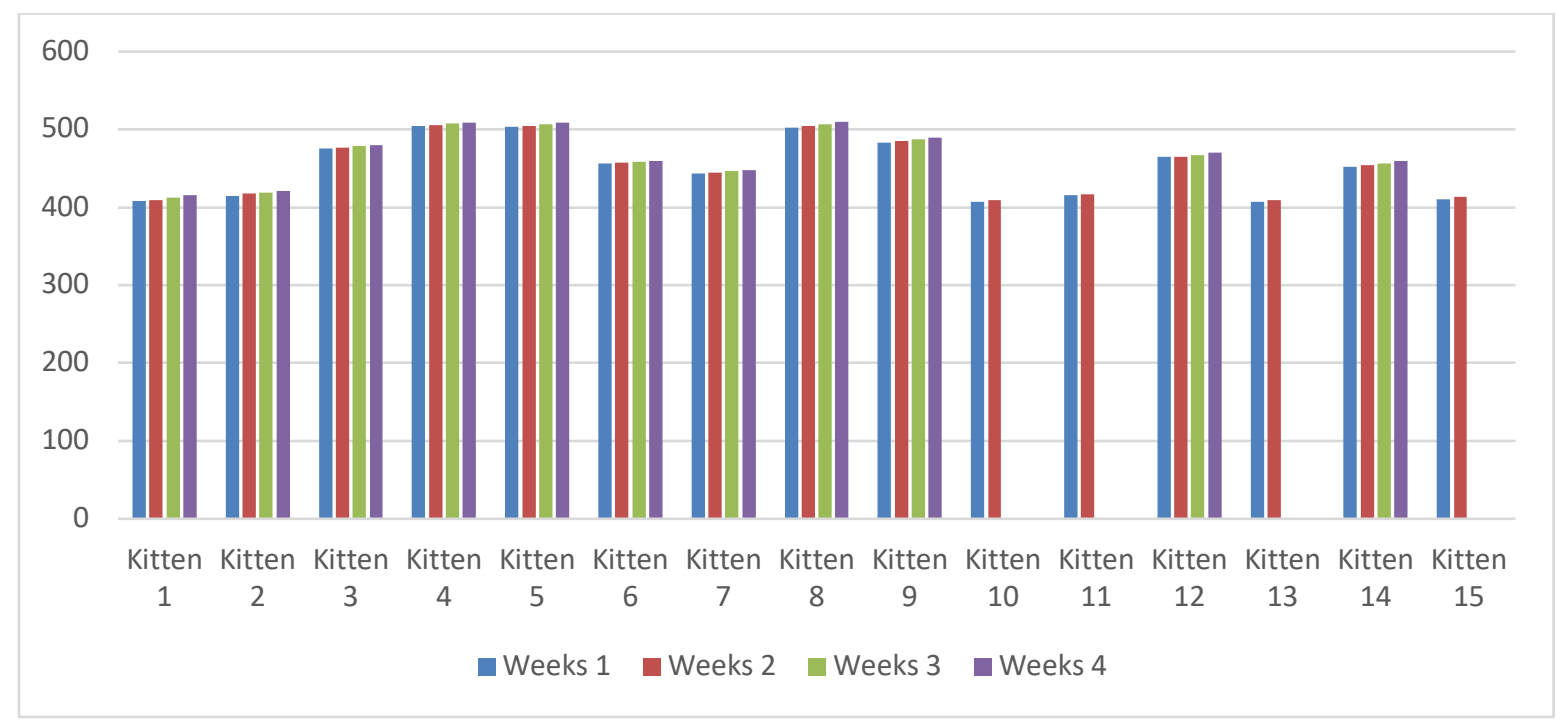

From the graph data above, it can be seen that the weight of the kitten has changed and some has not. This is influenced by the consumption of ginger extracts in cat food to warm the body and is also believed to have anti-inflammatory properties that serve to relieve pain

\section{SUMMARY}

From the feeding data, the role of ginger and ginger has a role that is no less important for the health of cats. The occurrence of dead cats in this study has the possibility that the cat has a fairly weak immune and poor digestive system that makes it possible for digestive diseases such (Muchlis, 2020). 
as diarrhea, after diarrhea appears usually

the cat has decreased appetite.

With the existence of temulawak extract in cat food, it can be used to help increase the cat's appetite so that when the appetite starts to improve it is usually accompanied by a digestive system that starts working normally.

\section{REFERENCES}

Dede, F. (2012). Berat Badan Ideal untuk Kucing. Banjarmasin: Salmon Petshop.

Hewson-Hughes AK, V. H.-H. (2011). Geometric analysis of macronutrient selection in the adult domestic cats, Felis catus. Jakarta: J Exp Biol.

Muchlis, A. (2020). Manfaat jahe yang tidak cuma penghangat badan tapi juga penangkal virus corona. Jakarta: Kompas.com.

Triakoso, N. (2016). Kesehatan dan Resiko Penyakit Akibat Pakan Kucing. Pakan dan Kucing. 